Mini Review

\section{Strobilurins: New group of fungicides}

\author{
Rasha E Selim* and Mohamed S Khalil
}

Agricultural Research Center, Central Agricultural Pesticides Laboratory (CAPL), El- Sabaheya, Alexandria, Egypt

\section{Abstract}

Strobilurin is a group of natural products and their synthetic analogs have been widely used to control and prevent fungal diseases. Strobilurins were firstly isolated in 1977 from the mycelium of Strobilurus tenacellus, a saprobic Basidiomycete fungus causing wood-rotting on forest trees. This group of pesticides was designed to manage fungal pathogens classes such as Ascomycetes, Basidiomycetes, and Oomycetes. Also, Strobilurin commercialized included derivatives such as are azoxystrobin, kresoxim-methyl, picoxystrobin, fluoxastrobin, oryzastrobin, dimoxystrobin, pyraclostrobin and trifloxystrobin. This group is a part of the larger group of Qol inhibitors, which act to inhibit the respiratory chain at the level of Complex III. Strobilurins group control an unusually wide array of fungal diseases, included water molds, downy mildews, powdery mildews, leaf spotting and rusts. This group are used on cereals, field crops, fruits, tree nuts, vegetables, turfgrasses and ornamentals. Also, Strobilurins found to enhance the plant growth in some cases.

\section{More Information}

*Address for Correspondence: Rasha E Selim, Agricultural Research Center, Central Agricultural Pesticides Laboratory (CAPL), ElSabaheya, Alexandria, Egypt, Email: salah.capl@gmail.com

Submitted: July 21, 2021

Approved: August 09, 2021

Published: August 10, 2021

How to cite this article: Selim RE, Khalil MS. Strobilurins: New group of fungicides. J Plant Sci Phytopathol. 2021; 5: 063-064.

DOI: 10.29328/journal.jpsp.1001062

Copyright: @ 2021 Rasha E Selim, et al. This is an open access article distributed under the Creative Commons Attribution License, which permits unrestricted use, distribution, and reproduction in any medium, provided the original work is properly cited.

Check for updates

OPEN ACCESS

\section{Introduction}

Strobilurin compounds are fungicides which belong to group of natural products and their synthetic analogs. Fungicides have been widely used in agricultural fields for decades. These pesticides are designed to manage fungal pathogens, although their broad-spectrum mode of action also produces non-target impacts [1]. Moreover, strobilurins are part of the larger group of QoI (quinone outside inhibitor), which act to inhibit the respiratory chain at the level of Complex III [2]. Strobilurine compounds isolation and structure elucidation of strobilurin A from wood-rotting mushroom fungi [1]. Some compounds such as azoxystrobin (Quadris), trifloxystrobin (Flint), pyraclostrobin (Cabrio), or Pristine (pyraclostrobin + boscalid) are belong to older strobilurins.

Strobilurin (QoIs) is very important class of respiration inhibitors that the biggest companies of pesticides have it in their portfolio, with a distributor sales value of US\$ 3.4 billion in 2016, they currently represent almost one-fourth of the world fungicide market (US\$15.3 billion in 2016). At the meaning time, 11 different strobilurins have been introduced into the world fungicide market in countries.

Recently, several new strobilurins have been announced as being developed or launched in China only (e.g. enestroburin, fenamistrobin, pyraoxystrobin). One strobilurin has also been commercialized as an acaricide (fluacrypyrim) according to McDougall [3]. strobilurins cause acute toxicity against germinating fungal spores, and relatively low toxicity for terrestrial animals.

\section{Antifungal activity of strobilurins}

Strobilurins are control a wide range of fungi classes such as; Ascomycetes, Basidiomycetes and Oomycetes. strobilurins control certain diseases which caused by water molds, downy mildews, powdery mildews, leaf spotting and blighting fungi, fruit rotter and rusts. Also, they are used on a wide variety of crops, including cereals, field crops, fruits, tree nuts, vegetables, turfgrasses, and ornamentals [4-6]. Kresoxim-methyl and trifloxystrobin are only moderately active against many Oomycete diseases, such as grapevine downy mildew $[7,8]$ and give less activity against number of Basidiomycete classes, such as wheat and barley brown rusts [9], Metominostrobin also is moderately active against Oomycete classes [10].

Strobilurins recorded some beneficial physiological effects on crop yield due to promotion of net carbon assimilation, nitrate reductase enzyme activity, stress tolerance and hormonal balance. In a study, kresoxim-methyl has been shown to cause changes in the hormonal system of wheat which results in increased grain yield, apparently from delayed leaf senescence and water-conserving effects [11].

Strobilurin fungicides recorded physiological changes in wheat and barley plants such as induced the antioxidative 
enzymes [12,13] and nitrate reductase [14,15], as well as changes in phytohormones levels [16]. However, it was found that Strobilurins inhibits sterol biosynthesis in some plants $[12,13]$.

\section{The fungicidal action of strobilurins}

Strobilurins have site-specific mode of action, through inhibiting fungal respiration at the $Q_{0}$ site in mitochondria [1721]. In another word, strobilurins act on fungal mitochondrial respiration, causing electron transport blockage in the cytochrome bc1 complex (complex III of electron transport chain), between cytochrome b and cytochrome $\mathrm{c} 1$, at the Qo site By inhibiting ubiquinol-cytochrome c-oxide reductase, they reduce the respiratory process blocking the fungus cell's energy supply (ATP), leading to its death, thus, they are also known as QoIs or inhibitors of the bc1 complex [10,20]. Because this complex is present in all eukaryotic organisms, there is at least partial inhibition of electron transport in plants when they come in contact with strobilurins such as pyraclostrobin and azoxystrobin which isolated from mitochondria in wheat plants [22].

\section{References}

1. Feng $\mathrm{Y}$, Huang $\mathrm{Y}$, Zhan $\mathrm{H}$, Bhatt Pand Chen S. An Overview of Strobilurin Fungicide Degradation:Current Status and Future Perspective. Front Microbiol. 2020; 11: 389.

PubMed: https://pubmed.ncbi.nlm.nih.gov/32226423/

2. FRAC. Qol-fungicides, FRAC code list 2011. www.frac.info

3. Philips McDougall. Agri Service. Products Section - 2016 Market.0 2017; 222-327.

4. Bartett DW, Clough JM, Godfrey CRA, Godwin JR, Hall AA, et al Understanding the strobilurin fungicides. Pestic Outlook. 2001; 12 : 143-148.

5. FAO Meeting. Azoxystrobin: Evaluation of Data for Acceptable Daily Intake and Acute Dietary Intake for Humans, Maximum Residue Levels and Supervised Trial Median Residue Values. 2008. http://www.fao.org/fileadmin/templates/agphome/documents/Pests_ Pesticides/JMPR/Evaluation08/Azoxystrobin.pdf

6. Jeschke P, Witschel M, Krämer W. Ulrich Schirmer (eds.): Modern Crop Protection Compounds, 3rd edition, Wiley-VCH. 2019.

7. Siegfried W, Holliger E. Strobilurine im Weinbau-neue Versuchsergebnisse zur Bekampfung des Echten und Falschen Mehltaus. Schweiz Z Obst-Weinbau. 1998; 4: 102- 104.
8. Broyard C, Margot P. La trifloxystrobine, une nouvelle substance active pour la protection fongicide de la vigne. Proc Sixieme Conf Internat Maladies des Plantes, ANPP, Tours. 2000; 935-942.

9. Anon. Fongicides cereales, leaflet produced by Institut Technique des Cereales et des Fourrages, France. 2001.

10. Bartlett DW, Clough JM, Godwin JR, Hall AA, Hamer M. The strobilurin fungicides Pest Mana. Sci. 2002; 58: 637-744.

11. Vincelli $P . Q_{0} I$ (Strobilurin) Fungicides: Benefits and Risks. The Plant Health Instructor. 2002

12. Wu YX, von Tiedemann A. Physiological effects of azoxystrobin and epoxiconazole on senescence and oxidative status of wheat. Pestic Biochem Physiol. 2001; 71: 1-10.

13. Wu $Y X$, von Tiedemann A. Impact of fungicides on active oxygen species and antioxidant enzymes in spring barley (Hordeum vulgare L.) exposed to ozone. Environ Pollut. 2002; 116: 37-47. PubMed: https://pubmed.ncbi.nlm.nih.gov/11808554/

14. Kohle H, Grossman K, Retzlaff G, Akers A, Limburgerhof G. Physiological effects of the new fungicide Juwel on yield in cereals. Gesunde Pflanzen. 1997; 49: 267-271.

15. Glaab J, Kaiser WM. Increased nitrate reductase activity in leaf tissue after application of the fungicide kresoxim-methyl. Planta. 1999; 207: 442-448.

16. Grossman K, Kwiatkowski J, Caspar G. Regulation of phytohormone levels, leaf senescence and transpiration by the strobilurin kresoximmethyl in wheat (Triticum aestivum). J Plant Physiol. 1999; 154: 805-808.

17. Sauter H, Steglich W, Anke T. Strobilurins: Evolution of a New Class of Active Substances. Angew Chem Int Ed Engl. 1999; 38: 1328-1349. PubMed: https://pubmed.ncbi.nlm.nih.gov/29711574/

18. Hnátová $M$, Gbelská $Y$, Obernauerová $M$, Subíková V, Subík J. Crossresistance to strobilurinfungicides in mitochondrial and nuclear mutantsof Saccharomyces cerevisiae. Folia Microbiol. 2003; 48: 496-500. PubMed: https://pubmed.ncbi.nlm.nih.gov/14533481/

19. Isamu $Y$, Makoto $F$. Recent topics on action mechanisms of fungicides. J Pestic Sci. 2005; 30: 67-74.

20. Balba H. Review of strobilurin fungicide chemicals. J Environ Sci Heal. 2007; B42: 441-451.

PubMed: https://pubmed.ncbi.nIm.nih.gov/17474024/

21. Rodrigues ET, Lopes I, Pardal MA. Occurrence, fate and effects of azoxystrobininaquaticecosystems:areview. EnvironInt.2013;53:18-28. PubMed: https://pubmed.ncbi.nlm.nih.gov/23314040/

22. Pedersen M, Wegner C, Phansak P, Sarath G, Gaussoin RE, et al. Monitoring wheat mitochondrial compositional and respiratory changes using Fourier transform mid-infrared spectroscopy in response to agrochemical treatments. Spectrochimica Acta Part A Molecular and Biomolecular Spectroscopy. 2017; 173: 727-732. PubMed: https://pubmed.ncbi.nlm.nih.gov/27788471/ 